Comparative Philosophy Volume 12, No. 2 (2021): 79-102

Open Access / ISSN 2151-6014 / www.comparativephilosophy.org

https://doi.org/10.31979/2151-6014(2021).120207

\title{
CONFUCIAN LEADERSHIP DEMOCRACY: A ROADMAP
}

\author{
YUTANG JIN
}

\begin{abstract}
What kind of polity is justified by classic Confucian values? Adopting an interpretive approach, this paper explores the idea of leadership democracy being expressive of classic Confucian values by first introducing the models of leadership democracy associated with Weber and Schumpeter and second connecting Confucian elitist values to them. I argue that leadership democracy best realizes the Confucian emphasis on the people as the source of legitimacy and the ruler as the engine of good governance. The Confucian idea of peoplerootedness is borne out by citizens behaving as democratic plebeians who are empowered to choose their leader but devoid of moral and intellectual capabilities for collective decisionmaking. The Confucian idea of rulership is expressed by democratic leaders displaying competent statesmanship and compensating for intra-elite tensions within the Confucian tradition.
\end{abstract}

Keywords: Confucian democracy, leadership democracy, Confucian political theory, Max Weber, Joseph Schumpeter

\section{INTRODUCTION}

Debates on the relationship between Confucianism and democracy have gone a long way from examining their compatibility to exploring various ways in which Confucian democracy can be justified and the particular shape it takes following its justification (Ames and Hall 1999; Angle 2012; Chan 2013; Kim 2018; Tan 2003). For many theorists today, Confucian democracy is no longer an oxymoron that defies the possibility of a happy union between two markedly different traditions (Huntington 1993; Levenson 1966). Instead, democracy gradually comes to assume a central place in scholastic discussion as "the only game in town". This trend, however, is widely contested by a constellation of scholars broadly identified as Confucian meritocrats. Their preoccupation is largely with reviving and making sense of meritocratic strands in Confucianism in ways that meet the challenges posed by the hegemony of liberal democracy (Bai 2008; Bai 2019; Bell 2009; Bell 2016; Jiang 2013; Kang 2005).

JIN, YUTANG: Postdoctoral Research Associate, Princeton University, USA. Email: yj1680@princeton.edu 
For many, normative proposals start with the philosophical reconstruction of Confucianism. Often availing themselves of multiple sources from different philosophical traditions (mostly Confucian and Western, both broadly construed), they participate in "a reflective project in cross-tradition engagement that has its focus on most-relevant aspects of the target texts from different traditions to a jointly concerned issue under examination" (Mou 2020, 140) where the jointly concerned issue is normative theories of democracy and meritocracy. In philosophical reconstruction, the "other" elements from different traditions that are "external" to each other have now become "internal" contributing parts that are necessary to reconstructed Confucian theories. Without delegitimizing the value of their intellectual pursuit, this article embarks on a related but different inquiry querying the scope of interpretation, which is a crucial issue largely glossed over by contemporary Confucians. An interpretive question typically asks what kind of Confucian polity is conceptually possible within the pedigree of Confucian thought - that is, whether Confucian thought justifies meritocracy or democracy and what kind of meritocracy or democracy follows such a justification. Philosophical interpretation and reconstruction are not exclusive of one another-they are simply different matrixes according to which an account can be evaluated independent of the author's intention. ${ }^{1}$

Interpretation here is not the same as seeking to "approximate the perspectives of past thinkers whose ideas are recorded in past texts"; rather, it closely resembles the "preliminary-engagement" phase of what Bo Mou $(2020,142)$ calls the "synchronicmultiple-dimension model" in cross-tradition engagement. In other words, my work seeks to understand and articulate Confucian standpoints in relation to the substantial issue of democracy, which does not refrain from deploying concepts and resources external to traditional Confucianism to capture and articulate various meanings of the Confucian text. But my approach nevertheless differs from Mou's model in two aspects: first, the interpretation I propose pursues not so much a comprehensive goal of crosstradition engagement but an understanding of the Confucian outlook as an end-in-itself. Second, the disciplinary pedigree both enacted and constrained by a particular tradition (in my case, Confucianism) is as important as the substantial issue under examination (the idea of democracy). In this sense, my interpretation pertains to the method of what Stephen Angle $(2012,9)$ calls "rooted global philosophy".

Why should we attend to the issue of interpretation in addition to philosophical reconstruction and normative configuration? Briefly, the scope of interpretation merits particular attention for two reasons. First, the way Confucian sources are invoked is an inquiry valuable for its own sake. It is worth asking, in line with the Confucian tradition, what the spirit of Confucianism is (Chan 2013, 5-17) and how the Way it displays (daotong 道統) (Makeham 2003) impacts on contemporary politics. For instance, in addition to asking what form of citizenship is normatively plausible and how different

\footnotetext{
${ }^{1}$ For instance, the fact that some Confucian democrats intend to reconstruct Confucian philosophy by blending it with Western democratic values in pursuit of some synthesis does not preclude them from being evaluated from an interpretive perspective. Alternatively, a work solely focusing on interpretation can also be judged in terms of value from the perspective of reconstruction.
} 
sources, Confucian or not, can be amalgamated to support democratic citizenship, we may also ask what kind of citizenship the stretch of Confucian sources can support. Second, interpretation is an enduring tradition within which generations of Confucians have gone about their intellectual inquiry. Late Qing Confucians, Japanese Confucians in the late Tokugawa and early Meiji eras as well as twentieth century New Confucians in Hong Kong and Taiwan have all been concerned with, not only to what extentmodern values are plausible in their own right, but whether and how Confucian values support political modernity especially democracy (Paramore, 2016; Tseng, 2020). ${ }^{2}$ Does embracing modern values mean that we should dispense with the Confucian tradition? If not, how is it possible for one to forsake part of the tradition and still faithfully claim one's modern account as Confucian? Shunning the practice of interpretation, therefore, risks dismissing massive intellectual exercises that attempt to grasp the complex relationship between Confucianism and democracy.

That said, there are broadly three ways in which one can register a stance on the issue of interpretation. First, an interpreter can claim that her interpretation (whether meritocratic, democratic or hybrid) is the only faithful reading of the Confucian tradition. Second, a weaker claim is that one's interpretation is the best or the most faithful reading of Confucianism though there are many legitimate ways in which it can be read and interpreted. Finally, an even weaker position than the second one is that one's interpretation is one among many possible interpretations of Confucianism, each of them palatable in different contexts. The last stance verges on seeking compatibility between Confucianism and democracy by reinterpreting some Confucian texts and is most accommodative in terms of its interpretive strategy.

In light of the three stances above, the core argument I make in this article - that core ideas of classic Confucianism, which I recast as plebeian and elitist values, are delivered in what I call "Confucian leadership democracy" (henceforth CLD) — can be read in two ways depending on the context in which one situates my work. First, this article can be seen as pertaining to the second claim and proposing the most promising reading of Confucian texts within the legitimate boundary of interpretation. Some recent studies (Jin 2020), by focusing on Confucian meritocracy and participatory Confucian democracy, show that both of them overuse one aspect (either elitist or plebeian) of Confucian democracy while leaving other elements in limbo. Jin briefly sketched a realist Confucian democracy that combines democratic election with strong leadership, of which CLD is one variant, as the most plausible approach to understanding Confucian ethico-political demands. In this context, this work builds on, and extends, this account. Alternatively, one may understand my current piece as fitting into the third, "compatibility" category as it is also a standalone work that explores the overlapping area between Confucianism and democracy without assuming the

\footnotetext{
${ }^{2}$ It should nevertheless be noted that not all commentators agree that New Confucians worked within the interpretive canon. Angle and David Elstein 2012 tend to understand Mou Zongsan as offering Confucian reasoning for democracy (thus falling within the interpretive category), while Thomas Fröhlich 2017 views Tang Junyi, a contemporary of Mou, as advocating for civil-theological modern Confucianism that bypasses existing forms of Confucianism.
} 
interpretive superiority of CLD over previous views. Seen in this light, my work proposes an original way of rendering Confucianism and democracy compatible without attempting to demolish its contenders.

With a conceptual setup in hand, we can proceed with our discussion. In the rest of the article, I first argue, by invoking Max Weber and Joseph Schumpeter, that leadership democracy is not a way of life offering tantalizing promises of participatory rights and collective decision-making but a cluster of institutions that hold the elite leader to account by providing them with incentives to compete for popular vote. Second, I discuss the sense in which Confucian plebeian values are borne out by citizens behaving as democratic citizens empowered to choose their leader but devoid of moral and intellectual virtues for collective decision-making. Finally, as a parallel case, I recast Confucian rulers as democratic leaders in leadership democracy by exploring their resemblances and how democratic leadership can deliver on Confucian elitist values.

\section{LEADERSHIP DEMOCRACY: WEBER AND SCHUMPETER}

Before we examine the close relationship between Confucian values and leadership democracy, it is worth briefly clarifying what the latter denotes. The leadership or competitive model of democracy ${ }^{3}$ as we know it today is often associated with Schumpeter. Its nascent form, however, can be traced back to Weber whose influence on Schumpeter was enormous (Osterhammel 1987). Weber's and Schumpeter's views on democracy are, first and foremost, responses to their respective social and political contexts (Eliaeson 1998; Medearis 1997, 820). For Weber (1978, 975), leadership democracy is largely a recipe for addressing problems associated with the hegemony of modern social and political forces, especially that of state bureaucratization in the age of modernity as an iron-cage. Schumpeter's concern, as noted above, is over "the classic doctrine of democracy", which is an uneasy blender of post-Enlightenment, utilitarian and Rousseauian elements (Held 2006, 149-150; Plamenatz 1973, 96-99). Despite their different concerns, the forms of democracy that they delineate are strikingly similar and I will focus on what they share in common as a starting point. Weber's "plebiscitarian leadership democracy" is a political mechanism by which the people exercise control over politicians and competent leaders are selected (Weber, 1994, 339). The Schumpeterian model of democracy also puts at the center a dynamic interaction between leaders and the electorate, which refers to "that institutional arrangement for arriving at political decisions in which individuals acquire the power to decide by means of a competitive struggle for the people's vote" (Schumpeter 2010, 269).

The primary feature of leadership democracy is the lopsided relationship between the powerful political elite and democratic citizens deficient in capacities needed for coping with complex governance issues. Democracy for Weber $(1978,985)$ is not the

\footnotetext{
${ }^{3}$ Weberian and Schumpeterian types of leadership democracy are by no means identical. My emphasis is on the common ground of elitist democracy shared by Weber and Schumpeter.
} 
"greatest possible rule of the demos but the party leaders of the demos" because the "shapeless mass" never govern themselves or large associations. Weber $(1994,326)$ likens the political structure of representative democracy to a firm controlled by shareholders' meeting in which it is not shareholders, but "the board of trustees" that wields real influence and makes important decisions on whom to recruit for management. It is therefore natural that the leader of the Caesarist type grows out of democracy whose efficiency "depends on the position of the Caesar as a free trustee of the masses who is unfettered by tradition" (Weber 1978, 961). Schumpeter goes further than Weber in attacking a particular way of understanding democracy as a political exercise by which the popular will directly translates into policy and law (Miller 1983). Schumpeter $(2010,254)$ argues that there is no such thing as the "popular will," and even if we take the majority preference as the popular will, it may turn out that "nondemocratic agencies may be more acceptable to the people than democratic bodies". 4 A democratic leader is interested not so much in popular demand directly as in amassing popular vote for election success the same way suppliers in the market are mainly driven by economic benefits, not by satisfying consumer desires directly (Miller 1983, 134).

For both Weber and Schumpeter, political leaders are, as they should be, trained in political struggles for power. The training and formation of responsible political leadership requires as necessary conditions partisanship and parliament - especially a parliament that does not practice "negative politics" but is endowed with real functional power. For Weber $(1994,339,351)$ "the creation of party machines...means the advent of plebiscitarian democracy", and "the only choice lies between a leadership democracy with a 'machine' and democracy without a leader, which means rule by the professional politician who has no vocation, the type of man who lacks precisely those inner, charismatic qualities which make a leader". By the same token, "The purpose of parliamentarization" is "to turn parliament into a place where leaders can be selected or train politicians who can assume leadership posts" (Weber 1994, 251). Schumpeter $(2010,246)$ explicitly suggests replacing the notion of "government by the people" with that of "government approved by the people". What results is a reversal of the sequence by which "the deciding of issues by the electorate" is made "secondary to the election of the men who are to do the deciding" (Schumpeter 2010, 269; emphasis added). The particular merit of Schumpeter's model is his emphasis on elite competition for votes, which differs from the notion of representation which carries its own paradoxes (Pitkin 1967). As Ian Shapiro $(2009,58)$ accurately points out, the drastic move made by Schumpeter is from the language of representation to that of consumer sovereignty. Here Schumpeter goes further than Weber in focusing on the competitive nature of leadership democracy, which not only offers an accurate depiction of the way democracy works in reality, but also brings forward the vital role

\footnotetext{
${ }^{4}$ One of distinctive contributions of Schumpeter lies in his rejection of the classic doctrine of the popular will. See the symposium on Schumpeter in Critical Review: A Journal of Politics and Society (2017) 29:4.
} 
of political leadership, which he takes to be neglected by many democratic theorists of his day.

For both Weber and Schumpeter, a plausible account of democracy does not give effect to the idea of self-legislation by which the people exercise collective self-rule. From Weber and Schumpeter, we can then retrieve a realist version of democracy in which the political elite are motivated to seek "public acclamation" through competitive election. Leadership democracy gives more weight to the democratically elected leader than it does to the electorate in shaping the political agenda. Despite challenges on many fronts, this basic model still offers a sense of "historical felicity"(Dunn 2014, 2) and empirically delivers on democratic promises around the globe (Przeworski 2010). One caveat here is that CLD does not need to accept all features and premises of leadership democracy as associated with Weber and Schumpeter; rather, its basic structures of election and leadership serve as a point of reference for my interpretation of Confucian values.

How does this leadership model of democracy then relate to Confucian values? Given that the issue at stake revolves around the nexus between elite and people and CLD depends for its intelligibility on how this nexus is conceived, I shall discuss Confucian notions of the people and leaders and how they relate to the leadership model. My primary purpose in the following discussion is to demonstrate the way in which the telos of classic Confucian thought requires the leadership model of democracy.

\section{THE PEOPLE AS DEMOCRATIC PLEBEIANS}

In classic Confucian texts, ${ }^{5}$ the most frequent terms of reference for the people are $\min$ (民), zhong (眾), and bai-xing (百姓), among others. Pinning down the normative weight of the people in overarching Confucian ethical-political order, however, is a complex matter. Often the image of the people and the role they play change dramatically depending on the particular textual context and the prefix associated with the people that implies moral judgement. Let me start with one of the most tantalizing accounts of the people's political role as legitimizing power transfer. In 5A5 and 5A6 of the Mencius, Mencius takes on Wanzhang, one of his disciples, in relation to issues involved in power transfer. Wanzhang asks whether it is true that Sage-King Yao gave power to another Sage-King Shun. Mencius replies that "the King cannot give the empire to another" but can only "recommend" his successor to Heaven and seek a Heavenly Mandate. Mencius continues, "Yao put Shun in charge of ritual sacrifices, and the various spirits were pleased with him. This was Heaven accepting him. He put Shun in charge of affairs, and the affairs were well-ordered, and the people were at ease with him. This was the people accepting him" (Mencius 5A5, 5A6; emphasis added). A similar justificatory pattern is offered following Shun's abdication to $\mathrm{Yu}$ and the succession of Yu by his son Qi.

\footnotetext{
${ }^{5}$ By classic Confucianism, I primarily refer to the Analects, the Mencius, and the Xun-Zi, which constitute the very core of the Confucian intellectual tradition. I will also touch on other texts including the Book of Rituals where they can help to strengthen the case I make.
} 
The message conveyed by Mencius is that power transfer is legitimated by the people being at ease or content (an 安) with the ruler in charge, in addition to the requirement that no natural anomalies happen. These passages are joined by others that justify rightful rebellions in terms of protecting the wellbeing of the people (Mencius 1B8, 7B4). For Mencius, "the people are of supreme importance; the altars to the gods of earth and grain come next; last comes the ruler" (Mencius 7B14). For some theorists, these anecdotes display democratic tendencies in Mencius given that the people are so conceived as having an impact on the choice of the ruler (Cheng 1979; Tu 2002). Commentators, however, disagree over whether the people, so conceptualized, are active political agents sanctioning a mandate to govern or passive signs of political legitimacy and whether they act on opting for the ruler themselves or should be guided by distinguished feudal lords at the time of power transfer (Angle 2012, 37-41; El Amine 2015, 37-51; Kim 2011; Nuyen 2013; Tiwald 2008).

The interpretive question can be put as follows: do Mencian ideas require monarchical rule or actually support democracy and only reluctantly accommodate the monarchy? If it is the latter, then the claim made by many New Confucians including Mou Zongsan and Xu Fuguan that Confucianism requires democracy makes much more sense than is usually assumed. Answering the interpretive question, however, is not easy. As Chan $(2013,15)$ puts it, "it is unclear whether the Confucian idea of having one Sage King to exercise supreme authority is necessarily a part of this ideal or merely a product of adaptation to nonideal conditions." Nevertheless, let's set about addressing this interpretive issue.

One of the obstacles that blocks a democratic reading is the lack of agency on the people's part in initiating and sustaining the legitimation process in the Mencius, which can be further perceived from two aspects. First, whether it is peaceful royal transmission between sage-kings or a tumultuous rebellion against the corrupt king, there seems to be always a discrepancy between those who lead in acting on the process (tian-li 天吏) and those with respect to whom the process is justified (the people) (Tiwald 2008, 274-277; Kim 2011, 382; El Amine 2015, ch. 1). Second, the intensity in terms of which the people are invoked varies depending on the mode of succession. The people's expression of contentment is required for non-hereditary succession while heredity is justified so long as no popular revolt is discerned, which leads some to argue that Mencius actually displays complicity in heredity (El Amine 2015, 40). If we appropriate Sheldon Wolin's distinction between politics and the political, we may claim that the upgrading of the people's role in Confucian power transfer features an episodic, political "moment of commonality" while their agency is minimized in everyday politics (Wolin 1994).

Why does Mencius accord supreme importance to the people while granting them no active agency? I suggest a line of reading according to which it is not so much the case that Mencius is naturally predisposed to confine the rights of rebellion and royal endorsement to the elite few but that he encountered the problem of making sense of the people's voice when its contour is amorphous. For Mencius, feudal lords and agents of Heaven are put in place, not for their own glory, but to give shape to the collective voice of the people, which Mencius takes to be crucial to the legitimacy of Confucian 
political order. In other words, it is the concern over setting clear and undisputable criteria for judging when and where there emerges a popular expression of contentment (or lack thereof), that makes Mencius end up embracing an arrangement in which the agents of Heaven interpret the people's action.

The reason for this plebiscitary reading lies in the particular way in which Mencius presents his case for popular expression. To illustrate, two contrasts between Mencius's account of what I incline to call "popular approval", and the idea of popular sovereignty as we find in the West, which is not necessarily tethered to democratic mechanisms, may help. First, because of the need to justify the supreme authority of the modern state, the modern idea of popular sovereignty, whether in Hobbes or Rousseau, presupposes a "supreme, irresistible, absolute, uncontrolled authority", (Morris 2000, 7) a kind of uniformity that requires a holistic notion of the people, which invites the problem of making sense of the people's voice. In contrast, Mencius' language of supremacy is mediated by the Heavenly Mandate, and the expression of contentment from the masses does not carry such compelling gravity toward holism as is required in the idea of popular sovereignty. For Mencius, the people being decisive therefore does not necessarily imply their acting in unison, but allows for a cacophony of plebeian people's concerns. ${ }^{6}$ Second, underlying many contractarian accounts of popular sovereignty is also the idea of hypothetical consent, which "rested on what people would agree to if they were rational" (Chambers 2004, 154) while, for Mencius, it is not hypothetical scenarios but the people's real feeling that is at stake. Confucian politics puts emphasis on the people's actual feelings not only because they confer authority on rulership, which points to the people as the "conduit of the state's legitimacy" (Angle 2012, 39), but also because Confucian rulership, instead of manipulating an artificial expression of the people, always builds their perfectionist governance on respect for the people's natural life including their sentiments and expressions as valuable in itself (Xu 2013, 479-484).

Given that Mencius's idea of popular approval distances itself from holistic and hypothetical orientations associated with popular sovereignty, it is therefore not too farfetched a claim that were there more tangible ways of giving effect to such an expression, Mencius would have willingly done away with his original arrangement. In line with existing readings (Chan 2007), my claim is not that Mencius did duck the feudal lords along with their liabilities such that democracy as an institutional measure is readily available in the Mencius. Nor is my claim simply that Mencius's original view should be altered in light of normative standards of modern times. Rather, my stand here is that Mencius's idea of popular approval would call for a more egalitarian arrangement than the original one on offer should its own potential be fully unleashed. Consequently, if we drop the temptation to associate Mencius with the popular will and instead connect the "contentment of the people" to the sense in which the elite are made

\footnotetext{
${ }^{6}$ Joseph Chan understands Mencius's popular approval as consent, and he is correct that the popular sovereignty grounded in consent is not the same as democracy. He, however, shows a misreading of Mencius insofar as there is no indication that the people's acceptance in Mencius should take a holistic or consent-like form, which is typical of understandings of popular sovereignty in early modern England. For Chan's view, see Chan 2007.
} 
responsive to the people's feelings, that is, if we measure popular feelings by appealing to "formal institutions" (Chan 2007), we may find Mencius's plebeian values better preserved and accentuated in democracy than in non-democratic regimes.

The pathway to Confucian democracy can be reinforced by forsaking the idea of falling back on the people as constitutive of emergency measures at the time of turmoil and instead rendering democracy normal and regular. A compelling Confucian case can be made for the mandate to rule to be constantly renewed rather than hover over the ruled until the ruler becomes too corrupt. In classic texts, the people's feelings only matter explicitly at the extraordinary moments of political change and the weight of their expressed feelings is diminished during peaceful, dynastic rule. As a result, the hereditary king cannot be removed just by virtue of the fact that he fails to measure up to the expectation of the people. The very source of the move from the extraordinary to the ordinary can actually be reasonably extrapolated from classic Confucianism. The idea of respect for the people manifests itself in the entries in the Mencius prescribing that, when promoting the worthy, the ruler follows the voice of "all men in the capital", not just that of her close attendants and counsellors; and that "there is a way to win their (the people's) hearts; amass what they want for them; do not impose what they dislike on them" (Mencius 4A9). The message is more straightforward in the Great Learning (12) saying that "what the people like, (the ruler) likes; what the people hate, (the ruler) hates". A corollary of respect for the people is thus a "politics of inexertion" (wuwe $i$ 無為) that cautions against the ruler's trampling upon what the people want for themselves and improves their moral discipline on that basis (Slingerland 2007; Xu 2016, 32-33). Delivering election-based democracy on a regular basis, therefore, can provide objective conditions under which a ruler is always responsive to what the people want - not doing so would be at the peril of forsaking his own office. Under such conditions, the ruler is institutionally bound to follow what the people want for themselves rather than free to interfere with their life at her whim.

While Mencius's thought — or the Mencian spirit — is much more democratic than we usually think, one hurdle is still stuck in the way that questions the rationale behind the people's action. So far, I have used such terms as "expressions" and "feelings" to refer to the forms in which the psychological status of an, or the people's contentment, is given tangible shape. For some commentators, the passive, affective and perhaps spontaneous form of political action on the part of the people means that the people are only indicators of Heaven's approval rather than active agents whose deliberation and judgement count in deciding on state affairs. The first is equivalent to asking of voters their opinions on whom they want in office while the second resembles sampling public opinion to justify one's own public work. The striking implication of this view is that the people only passively respond to what the leader did in the past (Tiwald 2008, 279). This line of argument is not so much about who is entitled to initiate political action, which has been addressed above, but about what kind of political action is required for acting on democratic participation. Indeed, if we look at the larger picture of classic Confucianism, the Confucian masters took pains to emphasize the impotence of the people in terms of both intelligence and virtue and why they can only be made to follow (De Bary, 1996: 19-20). For Confucius, min are often depicted as the masses that need 
to be tamed and educated (Analects 12.19). In the Mencius, the people's role is constantly likened to that of the petty person (xiao-ren 小人), the latter of which often points to those despicable personalities captivated by trivial and ignominious motives (Mencius 3A4, 6A14, 6A15). Similarly, Xun Zi ridicules "the virtue of min" as the habit of blindly following customs, being drawn to pecuniary benefits and treasuring prolongation of one's life, which stands in contrast to that of the nobleman (jun-zi 君 子) (Xun-Zi, “Ru-Xiao").

There are three aspects about Mencius' understanding of the people's political capability that further demonstrate Mencius's natural affinity with leadership democracy rather than any of its alternatives. First, there is no compelling reason for setting the threshold of meaningful participation so high as to crowd out many nonactive forms of participation that fall within the range of democracy. The people's ability to participate is, after all, only required to such a level as is possible for them as democratic citizens to fulfil basic roles such as casting votes. Reciprocal deliberation and active judgement may be prerequisites for deliberative and participatory forms of democracy (cf. Gutmann and Thompson 1998, 52-94), but they are not necessary for the leadership models of Weber and Schumpeter. A realistic expectation of mass behavior is the aspect on which Weberian and Schumpeterian models and Confucian values converge. Indeed, one of the merits of leadership democracy is that it acknowledges that the people as the multitudes are incapable of governing themselves. Leadership democracy only requires that the people be able to feel and respond to their own interests and put in power whoever they believe is likely to act on their interests. Similarly, the basic postulates about the people in classic Confucianism are also that the people tend to be selfish, non-virtuous and intemperate, which is why they need to be constantly taken care of by the ruler. Each individual of them, short of education and commitment to ethical cultivation, is close to the petty person devoid of moral standards. It is true that there is a nascent idea of moral equality (everyone can become a Yao or Shun - both sage-kings) and educational equality (Confucius claimed that he teaches everyone without any discrimination) in classic Confucianism (especially in Mencius). However, first, equal moral potential or equal opportunities for education can hardly be the same as actual equality, let alone a justification of democracy. Second, it is also helpful to draw on Ames and Hall's (1987, 139-141) distinction between min as the collective masses often misguided by blindness and ignorance and ren as a human being in the context of personal self-cultivation. In the end, min, short of actual moral enlightenment, are able to express what they like and dislike (in terms of both raw desires and moral sentiments), which stays at the heart of Confucian political order and to which benevolent rulers should cater in order to legitimately stay in office (Mencius 4A9, 5A5, 7A31; Xun-Zi, “Wang-Zhi”). The task of the virtuous ruler is then to fulfil their basic needs and improve their moral wellbeing. ${ }^{7}$

\footnotetext{
${ }^{7}$ There is a scholarly disagreement on the degree of moral improvement in classic Confucianism. For Joseph Chan 2013 and Elton Chan 2019, for instance, Confucians are aimed at maximal moral enhancement which is regrettably constrained by non-ideal conditions. For El Amine 2015 and 2019,
} 
Second, although there is a congruence between leadership democracy and Confucian understandings of the people, one may further question whether the epistemic limit of the people along with other psychosocial constraints applied to them can prevent a democracy fulfilling tasks required of it. The challenge here is that leadership democracy may distance itself from the Confucian understanding of the people insofar as it is premised on functional public opinion of which Confucianism falls short. For instance, Bentham famously used the metaphor of "public opinion tribunal" (Bentham 1989, 76) to describe the way in which the people affect the official decision-making of the elected representatives. Schmitt $(2008,257)$ also avowed that "democracy is designed as the rule of public opinion", but if the electorate are myopic and ignorant - as classic Confucianism tends to assume - to such a level that they are incapable of forming an opinion of their own except for the matters directly related to their personal life, how can the public give effect to the mandate granted to the elite ruler? Public opinion, after all, differs from the "popular will" simpliciter discussed above in offering a rough contour of opinion constellations on matters of common concern. In the political science scholarship of the recent decades, however, any simplistic relationship of public opinion to policy matters is increasingly cast into doubt not least because of such factors as elite manipulation, media bias, and the fact that the public normally do not have opinions on matters beyond social and political saliency (Jacobs \& Shapiro 2002; Neuman 1986; Zaller 1992). As John Zaller's study shows, what matters for public opinion is the relative balance and overall amount of media attention to contending political positions. Consequently, as he puts it, citizens "do not have fixed opinion beforehand" but only "construct 'opinion statements' on the fly as they confront each new issue" (Zaller 1992).

If pessimistic views of public opinion carry some plausibility, it follows that functioning democracy does not necessarily presuppose informed public opinion, which helps to affirm that Confucian assumptions about the people's incompetence are enough to justify democracy. After all, all that is required of the electorate is their judging of the ruler's ability to govern and responsiveness to the electorate's personal concerns by retrospective voting, which is close to what Confucian masters get to say about the people's political behavior. Leadership democracy, by separating off the choice of the ruler from the collective choice of complex policies, gears itself up for the conditions under which public opinion does not come across as valid contributions from the public. This, in turn, sheds light on the distance between Schumpeterian democracy upon which CLD is built and classic doctrines modelled upon public opinion which provide some traces of Bentham and the two Mills, and of which Schumpeter is deeply skeptical. Also, under such conditions, retrospective voting can actually turn out to work remarkably well in the citizenry's interest. As Manin (1997, 179) argues, rejection of the incumbent can be more efficient than election based on the proposed policy as it is more certain from the electorate's perspective that the existing policy does not work to their benefit than that the promises made by the

however, common people are only expected to improve their moral status to such a level as is required by hierarchical political order. 
competing political elites can be fulfilled once they assume office. Retrospective voting, hence, can be as rational for citizens to opt for as any more in-depth deliberation and prediction of the public policy, if they can ever come close to measuring up to the latter undertaking. ${ }^{8}$

Finally, deep skepticism about the people's capability also stems from their reflection of something different from, if not entirely external to, their body natural. The people, after all, speak on behalf of Heaven, who is invisible and reifies itself through the "people's eyes and ears" (Mencius 5A5). According to this view, it is not the people themselves but Heaven that stands behind them, that is decisive, which undermines the idea of the people per se being decisive in popular approval associated with democracy. It is, however, not necessarily the case that the people speaking on behalf of deities contradict the idea that the people are decisive. If we venture to the early modern period of England when the modern idea of popular sovereignty was born out of the crossfire between parliamentarians and royalists, we may find that popular sovereignty loomed large ab initio not as the idea that the people speak for themselves, but out of a political context in which the people are so conjectured as communicating directly with, speaking on behalf of, the deity. Henry Parker, one of the earliest spokespersons for the modern idea of popular sovereignty, argued that God, through the people, chooses the hereditary kings as the ruler. The kings' power is not absolute but qualified by limitations set by fundamental laws and the people's representatives in Parliament. Should the limits be violated, the people through their representatives have the power to revoke their trust in the king (Morgan 1989, 27-28). This narrative looks strikingly similar to the story recounted by Mencius in which the feudal lords speak and act on behalf of the people to remove the corrupt ruler at the behest of Heaven. If the former case stands as a sufficiently intelligible variety of popular sovereignty, there seems no reason why the second cannot support Mencius's popular approval. What matters here is not so much who, taken at face value, is in charge but how the spiritual languages are manipulated in the service of popular approval.

\section{CONFUCIAN RULERS AS DEMOCRATIC LEADERS}

With reference to Mencius, I argued above that the plebeian value of Confucianism calls for democracy while the monarchy along with its hierarchical structure is not what Mencian thought genuinely requires. But how about the elitist value of Confucianism?

For Weber, it is inevitable, under the modern conditions of the industrialized mass society, that the leader of the Caesarist ilk emerges from the democratic process whose vocation lies in combatting the corrosive effects of self-serving bureaucrats and delivering on political leadership that presides over incessant power struggles. In

\footnotetext{
${ }^{8}$ Is there a tension between trusting people in choosing their ruler and being skeptical about their selfgovernance? I believe not. While examining rationales behind classic Confucians' support of plebeian values is beyond the scope of this article, we can reasonably postulate that the Confucians believe the people can gauge a leader's competence through a simple feeling of whether the leader delivers while fulfilling the people's demands is a colossal task required of the elite, so there is no inevitable tension.
} 
Schumpeterian democracy, the model of the elite being in charge remains largely unchanged, which is complemented by crucial competitive mechanisms by which the electorate as consumers choose from the politicians at loggerhead with each other competing for votes. This, of course, does not mean that political leadership cannot exist in more participatory democratic systems - after all, rhetoric and persuasion by leaders had a high profile in the Athenian ekklesia. Athenian leaders, however, were featured by their speaking and advisory functions and severely constrained by adult citizens' direct participation and collective decision-making from bodies largely chosen by lot (Ober 2009, 107). What is remarkable in leadership democracy is thus a large scope for political maneuvers reserved for the political elite who are democratically elected and only accountable to the electorate on a periodic basis. How does leadership democracy, then, best realize Confucian understandings of leadership? Put differently, how is it possible that Confucian elitist values can be better delivered in leadership democracy than in, say, meritocracy and participatory democracy?

Confucian political order is often allegorically characterized as a combination of "inner sagehood" and "outer kinghood" that depicts the political sphere as a natural flow from personal self-cultivation to family, state, and worldly affairs (Great Learning 1). At the center of this overarching ethical-political order resides the moral exemplar firmly committed to both self-cultivation and ramification of moral values to her surroundings, which constitute two sides of the same coin. It is no exaggeration to say that leadership along with ideal personhood associated with it is the most important factor in securing peace and delivering on the Confucian Way pivoted around such values as benevolence and righteousness. For Confucian masters, the question of who is in charge and the quality of order that one is able to deliver is inextricably interrelated. Without the virtuous ruler in charge, there is no possibility that the vision of Confucian politics can ever be brought into fruition. Says Confucius, "the rule of virtue can be compared to the Pole Star which commands the homage of the multitude of stars without leaving its place" (Analects 2.1) and also, "to govern is to correct. If you set an example by being correct, who would dare to remain incorrect" (12.17)? There are also ample anecdotes in the Mencius and the Xun-Zi directly associating the prevalence of the Way with the virtue of the ruler, and abysmal failures in ruling with the ruler's moral debilitation (Mencius 1A5, 1A7, 1B8, 2A5, 7A13; Xun-Zi, "Wang-Zhi," "JunDao," "Qiang-Guo"). As Xun Zi's metaphor tellingly illustrates, the ruler is to the people as the headwater is to the river. Also, as William De Barry remarks, min recurrent in classic texts which I discussed above often appear in conjunction with, and recognition of, rulership (jun 君) and ideal personhood (jun-zi 君子) (De Bary 2004, 4-7).

The interpretive question vis-à-vis leadership is as follows: how does leadership democracy preserve Confucian elitist values? The first way in which leadership democracy can substantiate Confucian elitist values lies in its durability and pliability in combining the ruler's responsiveness to the people's demand, with a large scope of flexible action required by political leadership. For one thing, as I mentioned above in discussing Confucian leadership styles, a Confucian ruler ought to practice the "politics of inexertion" by which he commits himself to respecting what the people like and 
dislike for themselves, meaning that a ruler should refrain from imposing on the people the values and policies at his whim. A leadership democratic structure can guarantee, in institutional terms, that the ruler does not arbitrarily impinge upon the way ordinary people go about their daily life insofar as the democratically elected leader's power is subject to the terms set by the regular mandate granted by the electorate. For another, the overarching concern of the Confucian masters lies in delivering on good governance by not only meeting the basic material needs of the people (Mencius 1A3, 1A5, 1A7, 2A5, 3A3) but also improving and sustaining their moral caliber (Mencius 1A3, 1A7, 3A3, 6B8, 7A14, 7A20). Some contemporary theorists have reformulated Confucians' concern over the qualities of political order as Confucian perfectionist governance. ${ }^{9}$ In effect, the politics of inexertion, or $w u$-wei statecraft, already embodies the idea of benevolent politics, which requires the ruler set upon themselves the task of displaying an exemplary ethos and inspire the people towards the moral good (Slingerland 2007, 144-147). As the Confucian masters relentlessly avow, the quality and success of Confucian perfectionist governance rests on the moral disposition and judgement of the ruler in charge, and much less on other factors such as law, punishment and institutional mechanisms. In this light, leadership democracy, by reserving a special sense of vocation for Confucian rulers who are now recast as democratic leaders, can preserve much of the power traditionally wielded by the Confucian rulers while circumscribing the extent to which this power is misused to the detriment of Confucians' plebeian concerns.

One of the reasons that leadership democracy can keep track of both plebeian and elitist values in Confucianism remarkably well lies in the way a leader emerges from political struggles in this model, which brings about the second aspect of its congruence with Confucian elitist values, namely that the leader of an elite character inevitably emerges from the democracy thus conceived. Indeed, an acute problem of which Confucian meritocrats often charge their democratic counterparts is the dilution of elite elements in Confucian political thought if we appeal to democratic electioneering. Democracy is either depicted as the idea of collective decisions directly made by the people or as a formal process by which political demagogues sway the electorate by (illegitimately) promising benefits in return for putting them in office. Neither depiction, however, squares with the idea of leadership democracy.

Among Confucian democrats, Joseph Chan ${ }^{10}$ comes closest to my account by identifying electoral democracy with the selection model-which he originally takes from Jane Mansbridge (2009) — under ideal conditions. The basic idea is that democratic elections can function as an efficient way in which responsible leaders are selected (Chan 2013, 73-79). He promptly waters down the elitist flavor of his account, however, by claiming that the selection model is not necessarily aristocratic but can, as

\footnotetext{
${ }^{9}$ Pertinent examples are Joseph Chan's moderate Confucian perfectionism and Sungmoon Kim's public reason Confucianism.

${ }^{10}$ While some commentators prefer labelling Chan as meritocratic (see Kim 2018), Chan nevertheless differs crucially from meritocrats such as Daniel A. Bell and Tongdong Bai in granting a decisive role to the democratically elected body of legislation, and further in justifying democratic institutions in Confucian terms, which is why I put him in the democracy group here.
} 
it should, accommodate the egalitarian idea of likeness - the idea that voters choose leaders who resemble them - that structures political representation in contemporary Western liberal democracies (Chan 2013, 79). The difficulty with his view is that he assumes as problematic, rather than explains away, the realistic view of the vast majority of the people as lacking virtues and political competence and a normative vision that aspires to the aristocratically oriented elite being in charge. Consequently, his strategy is dismissing the "old understanding" of the selection model as revolving around "hierarchy and distinction" (Chan 2013, 78). While Chan believes that the idea of likeness does not imply a mediocre representative with average abilities, he nevertheless favors a democratically elected leader committed to cultivating likeness, whatever elitist merit she possesses. As controversial is the implications of his retreat into the idea of likeness, which blinds us to the crucial aspect on which Confucians' relentless emphasis on elitist leadership and the aristocratic feature of electoral democracy converge. Partly because of his lack of confidence in the elitist character of democratic elections, Chan readily joins Confucian meritocrats in envisioning a meritocratic chamber constitutive of non-electorally selected elites that stands independent of the democratically elected chamber. ${ }^{11}$

In this light, the democratic part of Chan's theory preserves elite power but is hardly elitist in orientation. It is, however, no surprise that Chan is keen on severing democratic elections from distinctive aristocratic tendencies. Evidently, election as an aristocratic method of selecting leaders did not come to be associated with democracy until the advent of modern representative democracy after the American and French Revolutions. According to Manin, election manifests its elite characters in at least four aspects: in the unequal treatment of candidates by voters according to the measures widely accepted, in the necessity of the candidates having superior qualities in a certain social and cultural settings, in the cognitive advantages granted by visual or charismatic salience, and finally in the cost of information that is unequally distributed and which is only affordable to someone at an social and political advantage (Manin 1997, 134148). In effect, the elite character of election was duly recognized by the Chinese as early as late Qing when such figures as He Qi and Hu Liyuan advocated, in their joint work known as the Truthful Demonstration of New Politics (Xin-Zheng-Zhen-Quan 新 政真詮), a unitary legislative body instead of the two-House system (He, 1994). They believed that a House of Lords would be redundant because a lower House alone is capable of promoting those intelligent and virtuous who are due to be recognized by all as their representatives.

There may, however, be doubts about the affinities between Confucian and Weberian (or Schumpeterian) leadership qualities. Weber $(1994,220)$ recognizes that the Caesarist leader emerging out of political struggles would excel at demagoguery swaying the voters by rhetoric and charisma. Manin $(1997,143)$ also argues that leaders

\footnotetext{
${ }^{11}$ I am not against the idea of the second chamber, though. My reasoning for the second chamber, which serves to preserve continuity and tradition, however, differs from both republicans' account of separation of powers and Confucian meritocrats' account of elitist power. This article, however, is not the place to expand on this idea.
} 
in representative democracy are only elite in appearance - instead of being truly noble, they are only perceived by the public as possessing elite characters in certain social and cultural settings. Admittedly, there are largely two aspects in which Confucian and Caesarist leaders may part company. First, in leadership democracy, the stakes are high in political struggles by which politicians engage in a complex process of persuasions and negotiations. For Weber, in order for a leader not to be purely demagogic, it is essential that she go through power struggles in partisan and parliamentary politics. In contrast, the direct flow from ethical self-cultivation to one's outer sphere of life in Confucianism means that a Confucian elite does not need to excel at political gimmicks in order to be able to lead. Instead, political and personal virtues are united in selfcultivation oriented towards moral goodness whether one is in office or not. When asked why not participate in politics, Confucius replied that "the Book of History says, 'Oh! Simply by being a good son and friendly to his brothers a man can exert an influence upon government.' In so doing, a man is, in fact, taking part in government. How can there be any question of his having actively to take part in government" (Analects 2.21)?

What follows from the first aspect is a divergence in the virtues or capabilities needed for a successful leader, which is the second aspect in which leadership democracy prima facie defies Confucian leadership. For Weber $(1994,352)$, the desirable qualities required of the leader, are a sense of passion about the beliefs for which one fights, a sense of responsibility by which one weighs the consequences for political action, and capabilities for shrewd judgement in changing circumstances. Underlying these desiderata is an acute awareness of the danger and frailty built into power relations in politics. For the Confucians, the cardinal virtues required in politics are of an overwhelmingly humanitarian nature, which include, among others, the virtues of benevolence, righteousness, ritual propriety, and wisdom. In other words, a Confucian leader needs to be vigilant to human sufferings and roll out benevolent policies to address them. Bell $(2016,60-61)$, for instance, picks up on the divergence here by holding democracy of one-person-one-vote responsible for the disruption of harmonious relationships constitutive of Confucian ethics. To borrow the market analogy, the Confucian leader not only plays along as suppliers interested in gathering votes but also directly attends to the fundamental wants and needs of ordinary people, which is markedly different from power-hunting politicians.

In response, we may say, first, that the fact that the idea of CLD piggybacks on leadership democracy does not mean that CLD needs to accept all features of its prototype. Some aspects of leadership democracy, in its original form, indeed sit ill with CLD. For instance, I do not deny Weber's obsession with charisma and demagogy which defies some Confucian leadership qualities; nor do I dismiss his understanding of modern political parties as bureaucratically organized apparatus which requires charismatic leadership to rein it in. Far from absorbing all theoretical premises of Weber and Schumpeter, CLD attempts instead to remedy the aspects of its protype that it finds problematic while keeping its conceptual intelligibility. Second, the gap between the spirit of Confucianism and leadership democracy is not so wide as it 
appears. Rather, leadership democracy can help weather problems inherent in traditional Confucian politics thereby restoring the spirit of Confucian elitism.

In terms of the extent to which leadership democracy conduces to Confucian elite qualities, three aspects are particularly worth highlighting. First, despite their different understandings of politics and merits required of political leaders, both leadership democrats and Confucians would regard resilience and elasticity, astute judgment as well as a commitment to serving public office, as particularly relevant to political leadership. Second, leadership democrats' attendance to power and the way it operates between elite and people demonstrate not so much their cynicism about moral concerns but their perspicacity in directly confronting and containing the dark side of politics. Weber (1994, 369), who champions Caesarist democracy, emphasizes the importance of combining passion with a willingness to cope with the consequences of one's action, the balance of which defines genuine vocational statesmanship. Third, as I noted in the section on plebeian values, one distinctive feature of Confucian wu-wei politics is the tremendous care that the ruler takes to cater to what the people actually want for themselves. In this light, that the democratic system is so designed as to give incentives for the elite to compete for popular votes does not prevent them cultivating broader senses of statesmanship. Far from undermining the nourishment of virtues, we can say that being attentive to popular demands and finding intelligent ways to address them is an integral part of Confucian $w u$-wei politics. ${ }^{12}$

The reason that the Confucian spirit supports and justifies leadership democracy can be further gleaned from the uneasy relationship between Confucian intellectuals and the traditional monarchy that have long troubled Confucianism throughout East Asian political history (De Bary 1996, 46-56). Traditionally, Confucian leadership was comprised of enlightened rulership and ministership that was put up to rectify the former's drawbacks. When I mentioned Confucian leadership, I meant both, but far from complementary, they were in constant tension. According to De Bary, what bedeviled Confucians' effort to bring about the benevolent Way is that Confucianism put upon the nobleman or scholar-officials (shi-da-fu 士大夫) all burdens of responsibility without giving valency to social forms and institutions. When despotism arises and wreaks havoc on the society, Confucians readily take the blame because they are supposed to break through the cant and the convention to give effect to the Way. Accordingly, one of the strains that tends to pull apart Confucian moral integrity is the issue of participation in politics (Eno 1990, 42-51). On the one hand, the protoparticipatory aspect of the Confucians can be found in the frequency with which moral principles are discussed in relation to governance. On the other hand, rulers were predominantly corrupt and egocentric and even Confucian masters struggled to find a ruler appreciative of their visions (Pines 2009, ch. 6 \& 7). While Confucius himself was never for or against anything, he enjoined others to "show yourself when the Way

12 Electoral competition is not sufficient for fostering Confucian wu-wei politics. Hyperbolic competitions in advanced democracies today acutely remind us of the need for further social ethos and institutional arrangements that preserve and entrench Confucian virtue cultivation among the elite. More on this in the conclusion. 
prevails in the Empire but hide yourself when it does not" (Analects 8.13). In a similar vein, Mencius fleshed out his view by claiming that "a Gentleman never abandons rightness in adversity, nor does he depart from the Way in success", which leads him to conclude that "in obscurity a man makes perfect himself, but in prominence, he makes perfect the whole Empire as well" (Mencius 7A9).

The upshot of this profound ambivalence towards political involvement against the backdrop of dynastic rule was an incessant feud among Confucian intellectuals. Some Shidafu chose to stay complicit in the ruler's brutality while aspiring to piecemeal reform and more audacious ones risked their life in acting on their conscience. Others chose to completely retreat from political affairs, which contributed to breeding a culture of reclusion that continued to plague Confucian orthodoxy. The rest came to profess a slavish devotion to supreme power, voluntarily turning the mark of the ruler. And let's not forget that many sycophants of the ruler were the beneficiaries of the civil examination system which the meritocrats boast about (Bell 2006, 153-154; Xu 1985, 56). One way out of this conundrum, which is at odds with the spirit of Confucianism, is readily proffered by leadership democracy, which, as a democratic institution, regulates political struggles within legitimate boundaries and keeps on board political opponents of all sides. A conscientious Confucian no longer needs to plunge into an impossible mission of reconciling their deeply cherished values with serving a ruthless monarch; rather, absent an autocratic ruler at the center, she can put herselfforward as a democratic leader by directly appealing to the public. The traditional worry of usurpation can be dissipated by the peaceful and legitimate transfer of power. In case she fails to secure power, the subsequent situation is no longer a black-and-white choice between serving those for whom she holds contempt and withdrawal from politics, but a dignified role as an opposition politician in parliament or as a vocal critic of the government in civil society without the fear of persecution.

Another trouble closely related to Confucians' political involvement is brutal factional strife (dang-zheng/dangjaeng 黨爭 in Chinese and Korean, also sahwa 士禍 in Korean) recurrent in pan-Confucian societies, which can also be creatively, if not entirely, addressed in CLD where regularized competition placates ideational disputes and keeps violence at bay. Whether it is Song and Ming dynasties in China when Confucian doctrines held sway, or the Chosun dynasty in Korea which enshrined Confucianism wholesale as guiding court philosophy, factional conflicts usually went amuck with scholar-officials of different strands within the Confucian tradition fighting for political dominance (cf. Levine 2008; Lee 2007). Ideological differences easily escalated into full-scale power confrontations, which usually ended up with bloodshed and ferocious persecution. A winner often emerged not only as a victor of power struggles but as someone entitled to the legitimate monopoly on interpreting the true Way. This, however, is in stark contrast to the anti-factional attitudes held by the Confucian masters. Although we find in the classic texts Mencius and Xun Zi resigned to acrimonious exchanges with heretics over the interpretation of the Way, Confucian ethical teachings are, at best, averse to verbal and factional disputes. Says Confucius, "what the gentleman seeks, he seeks within himself; what the small man seeks, he seeks in others," and also "the gentleman is conscious of his own superiority without being 
contentious and comes together with other gentlemen without forming cliques" (Analects 15.20, 15.20). Mencius was reluctant to engage in arguments though he found himself compelled to argue (Mencius 3B9). While Xun Zi exhorted the nobleman to embrace debates, he nevertheless posited that "(a nobleman) engages in argumentation, but not to the point of causing a quarrel; he is critical, but not to the point of provoking others" (Xun-Zi, "Bu-Gou”). Xun Zi further derided the human pursuit of dominance (zheng 爭) as arising out of a bad penchant for satiating natural needs and wants (Xun$Z i$, "Li-Lun," "Wang-Zhi"). Overall, Confucian ethical cultivation is motivated by a harmonious unity between body and world and constrained by ritual propriety, or simply put, the bonds of "civility" (Angle 2012, 91-110; Chan 2013, 90-91).

In CLD, in contrast, different vocations for Confucian beliefs can be accommodated with no need to obliterate one group for another to triumph, which invites three modifications of the traditional role played by Confucian intellectuals thereby restoring Confucian harmony in politics. First, Schumpeterian competition ensures that diverse Confucian voices can be put on an equal footing striving for the democratic mandate. Confucian intellectuals, recast as Confucian politicians and constrained by democratic mechanisms, can now bring themselves forward to competition rather than repression. In other words, the extent to which the electorate give effect to their confessed norms and values presides over, and mediates between, various Confucian groups or "parties". Second, the Confucian nobleman is no longer obliged to fight a solidary battle against the corrupted currents of politics, which is doomed to failure and contradiction. Instead, they can, as protagonists in leadership democracy, form, and coordinate through, political parties which resemble the parties of principles as defined by Burke (1999), or what Weber $(1994,193)$ calls the parties of a particular Weltanschauung. The flexibility and pragmatism built into Confucian ethics would render Confucian parties less uncompromising than they appear, but it is crucial, for them to stay as Confucian, that Confucians act on their understandings of the Way rather than on a hotchpotch of tactics lacking disciplines. Last but not least, Confucian noblemen need, in political terms, seriously to take on the petty person (xiao-ren, 小人), the antipode of dignity and noblesse embodied in the junzi. Physical extirpation is left out of the question; instead, conscientious Confucians need to either win them over by persuasion or defeat them in elections. In short, just as archery offers a condition where "the way (noblemen) contend is gentlemanly" (Analects 3.7; Behuniak Jr 2010), leadership democracy provides a venue for Confucians to win the battle in a civil manner and even if they fail to win, there is institutionally protected public space where they can repose and perform other civil duties in preparation for the next fray.

\section{CONCLUSION}

This paper started out by a discussion of the interpretative method. I argued that Confucian plebeian and elitist values are embodied in a particular, elitist type of democracy which I call Confucian leadership democracy. I have also gone to great lengths to explain why it is appropriate to alter some specific texts in order to preserve the spirit of classic Confucianism (e.g., popular approval, leadership, and harmony). In 
this way, I have gone a step further than New Confucians such as Mou Zongsan, Xu Fuguan and Tu Weiming in specifying what kind of democracy Confucian thought lends support to.

It should also be pointed out that not all types of leadership democracy are Confucian insofar as classic Confucian thought is the sufficient, though not necessary, condition of leadership democracy. Indeed, the family of leadership democracy can come with liberal, republican and Confucian variants (Posner 2005; Shapiro 2009). What then renders leadership democracy distinctively Confucian? In order to procure the Confucian attribute of leadership democracy, we also need Confucian habits and mores as the social ethos for citizens and the training mechanisms for leaders soaked in Confucian classics, rituals and norms, which are subject to a complex interplay with the institution of leadership democracy. Nevertheless, this article has fulfilled its moderate mission if the reader decides to open up to the possibility that leadership democracy is not antithetical to, but constitutive of, the spirit of classic Confucianism.

Speaking of this spirit may sometimes invite cynicism (Jenco 2017), but it is critical for Confucian societies in attending to the modernity issue beyond the East-West dichotomy. In East Asia today, especially China, there still exists a mindset of the antithesis between the traditional way of life which gives shape to one's own identity, and the way of life imported from the West. This almost intransigent view takes hold regardless of what one makes of this dichotomy in normative thinking. In stark contrast, the first generations of Confucian scholars following the first Opium War (1839-1842) including Xu Jiyu and Guo Songtao extolled the virtue of Western (both British and American) democratic institutions as a resurrection of the Sage-King era and therefore the culmination of the Confucian spirit. Their pioneering efforts to understand the rhythm of cross-cultural connections preceded the later turn to the doctrine of "Chinese learning as substance, Western learning for application" embraced during the SelfStrengthening Movement (1861-1895). This article shows that ideational connectivity is porous and dynamic, which may help us better understand what it really means when politicians and various interlocutors today speak of preserving the tradition and what is lost and preserved in the so-called process of Westernization.

\section{ACKNOWLEDGMENTS}

The early draft of this article is retrieved from my DPhil thesis. As always, I am indebted to Stuart White, Stephen Angle and Nicholas Bunnin, who supervised my study during my time at Oxford, for their detailed comments and kind support. I would also like to thank Daniel Butt and Joseph Chan, who provided phenomenal feedback on my work in their capacity as examiners of my thesis. I am also grateful to three anonymous reviewers of the journal Comparative Philosophy. 


\section{REFERENCES}

Ames, Roger and Hall, David (1999), The Democracy of the Dead: Dewey, Confucius, and the Hope for Democracy in China (Chicago: Open Court).

Angle, Stephen (2012), Contemporary Confucian Political Philosophy (London: Polity).

Bai, Tongdong (2008), "A Mencian Version of Limited Democracy”, Res Publica 14.1: 19-34. <https://doi.org/10.1007/s11158-008-9046-2>

Bai, Tongdong (2019), Against Political Equality: The Confucian Case (Princeton, NJ: Princeton University Press.

Behuniak Jr., James (2010), "Hitting the Mark: Archery and Ethics in Early Confucianism", Journal of Chinese Philosophy 37.4: 588-604. < https://doi.org/ 10.1111/j.1540-6253.2010.01606.x>

Bell, Daniel A. (2006), Beyond Liberal Democracy: Political Thinking for an East Asian Context (Princeton: Princeton University Press).

Bell, Daniel A. (2009), Beyond liberal democracy: Political thinking for an East Asian Context (Princeton: Princeton University Press).

Bell, Daniel A. (2016), The China Model: Political Meritocracy and the Limits of Democracy (Princeton: Princeton University Press).

Bentham, Jeremy (1989), First Principles Preparatory to Constitutional Code. (Oxford: Clarendon Press).

Burke, Edmund (1999), Philosophical Enquiry into the Sublime and Beautiful: And Other Pre-Revolutionary Writings. London: Penguin.

Chambers, Simone (2004), "Democracy, Popular Sovereignty, and Constitutional Legitimacy", Constellations 11.2: 153-173. <https://doi.org/10.1111/j.1351-0487. 2004.0370.x>

Chan, Elton (2019), “The Indispensability of Moral Cultivation in Confucian Politics", Dao 18.2: 269-276. <https://doi.org/10.1007/s11712-019-09660-9>

Chan, Joseph (2007), "Democracy and Meritocracy: Toward a Confucian Perspective", Journal of Chinese Philosophy 34.2: 179-193. <https://doi.org/10.1111/j.15406253.2007.00408.x>

Chan, Joseph (2013), Confucian Perfectionism: A Political Philosophy for Modern Times (Princeton: Princeton University Press).

Cheng, Chung-ying (1979), "Human Rights in Chinese History and Chinese Philosophy", Comparative Civilizations Review 1.1: 1-19.

De Bary, William Theodore (1996), The Trouble With Confucianism (Cambridge, MA: Harvard University Press).

De Bary, William Theodore (2004), Nobility and Civility: Asian Ideals of Leadership and the Common Good (Cambridge, MA: Harvard University Press).

Dunn, John (2014), Breaking Democracy's Spell (New Haven: Yale University Press).

El Amine, Loubna (2015), Classical Confucian Political Thought: A New Interpretation (Princeton, NJ: Princeton University Press). 
El Amine, Loubna (2019), "Material Conditions, Hierarchy, and Order in Early Confucian Political Thought: A Response to Reviewers", Dao 18.2: 285-289. $<$ https://doi.org/10.1007/s11712-019-09662-7>

Eliaeson, Sven (1998), "Max Weber and Plebiscitary Democracy", in in Schroeder, Ralph (ed.), Max Weber, Democracy and Modernization (London: Palgrave Macmillan), 47-60.

Elstein, David (2012), "Mou Zongsan's New Confucian democracy", Contemporary Political Theory 11.2: 192-210. <https://doi.org/10.1057/cpt.2011.23>

Eno, Robert (1990), Confucian Creation of Heaven: The Philosophy and the Defense of Ritual Mastery (Albany, NY: SUNY Press).

Fröhlich, Thomas (2017), Tang Junyi: Confucian Philosophy and the Challenge of Modernity (Leiden: Brill).

Gutmann, Amy and Thompson, Dennis F. (1998), Democracy and Disagreement (Cambridge, MA: Harvard University Press).

Hall, David L. and Ames, Roger (1987), Thinking Through Confucius (Albany, NY: SUNY Press).

$\mathrm{He}, \mathrm{Qi}$ 何啟 and Hu, Liyuan 胡禮垣 (1994), 《新政真銓》[The Truthful Demonstration of New Politics] (潘陽 Shenyang: 遼寧人民出版社 Liao-NingRen-Min-Chu-Ban-She).

Held, David (2006), Models of Democracy (Stanford: Stanford University Press).

Huntington, Samuel P. (1993), The Third Wave: Democratization in the Late Twentieth Century (Norman, OK: University of Oklahoma Press).

Jenco, Leigh (2017), "How Should we Use the Chinese Past? Contemporary Confucianism, the 'Reorganization of the National Heritage' and non-Western Histories of Thought in a Global Age", European Journal of Political Theory 16.4: 450-469. <https://doi.org/10.1177/1474885117703768>

Jiang, Qing (2013), A Confucian Constitutional Order: How China's Ancient Past Can Shape Its Political Future (Princeton, NJ: Princeton University Press).

Jin, Yutang (2020), "Between Political Meritocracy and Participatory Democracy: Toward Realist Confucian Democracy", Culture and Dialogue 8.2: 251-279. $<$ https://doi.org/10.1163/24683949-12340086>

Kang, Xiaoguang (2005), 《仁政：中國政治發展的第三條道路》[Humane Government: A Third Road for the Development of Chinese Politics] (Singapore: Global Publishing Co).

Kim, Sungmoon (2011), "Confucian Constitutionalism: Mencius and Xunzi on Virtue, Ritual, and Royal Transmission", The Review of Politics 73.3: 371-399.

Kim, Sungmoon (2018), Democracy After Virtue: Toward Pragmatic Confucian Democracy (Oxford: Oxford University Press).

Lee, Sungmoo (2007), 《조선시 대 당쟁사》[The Factional History of the Chosun Dynasty] (Seoul: Beautiful Day).

Levenson, Joseph R. (1966), Confucian China and Its Modern Fate (Berkeley, CA: University of California Press).

Levine, Ari D. (2008), Divided By a Common Language: Factional Conflict in Late 
Northern Song China (Honolulu, Hawaii: University of Hawaii Press).

Makeham, John (2003), New Confucianism: A Critical Examination (New York: Springer).

Manin, Bernard (1997), The Principles of Representative Government (Cambridge: Cambridge University Press).

Mansbridge, Jane (2009), “A 'Selection Model' of Political Representation”, Journal of Political Philosophy 17.4: 369-398. <https://doi.org/10.1111/j.1467-9760.2009. 00337. $x>$

Manza, Jeff et al. (eds), Navigating Public Opinion: Polls, Policy, and the Future of American Democracy (Oxford: Oxford University Press).

Medearis, John (1997), "Schumpeter, the New Deal, and Democracy", American Political Science Review 91.4: 819-832. <doi:10.2307/2952166>

Miller, David (1983), "The Competitive Model of Democracy", in Duncan, Graeme (ed.), Democratic Theory and Practice (Cambridge: Cambridge University Press), 133-155.

Morgan, Edmund S. (1989), Inventing the People: The Rise of Popular Sovereignty in England and America (New York: WW Norton \& Company).

Morris, Christopher W. (2000), "The Very Idea of Popular Sovereignty: 'We the People' Reconsidered", Social Philosophy and Policy 17.1: 1-26. < doi:10.1017/ S026505250000251X>

Mou, Bo (2020), Cross-Tradition Engagement in Philosophy: A ConstructiveEngagement Account (New York: Routledge).

Neuman, W. Russell (1986), The Paradox of Mass Politics: Knowledge and Opinion in the American Electorate (Cambridge, MA: Harvard University Press).

Nuyen, AT (2013), “The 'Mandate of Heaven': Mencius and the Divine Command Theory of Political Legitimacy", Philosophy East and West 63.2: 113-126. $<$ doi:10.1353/pew.2013.0014>

Ober, Josiah (2009), Mass and Elite in Democratic Athens: Rhetoric, Ideology, and the Power of the People (Princeton: Princeton University Press).

Osterhammel, Jürgen (1987), "Varieties of Social Economics: Joseph A. Schumpeter and Max Weber", in Mommsen, Wolfgang J. and Osterhammel, Jürgen (eds), Max Weber and His Contemporaries (London: Allen \& Unwin).

Paramore, Kiri (2016), Japanese Confucianism (Cambridge: Cambridge University Press).

Pines, Yines (2009), Envisioning Eternal Empire: Chinese Political Thought of the Warring States Period (Honolulu, Hawaii: University of Hawaii Press).

Pitkin, Hannah F. (1967), The Concept of Representation (Berkeley, CA: University of California Press).

Plamenatz, John P. (1973) Democracy and Illusion: an Examination of Certain Aspects of Modern Democratic Theory (London: Longman Publishing Group).

Posner, Richard (2005), Law, Pragmatism, and Democracy (Cambridge, MA: Harvard University Press).

Przeworski, Adam (2010), Democracy and the Limits of Self-Government (Cambridge: Cambridge University Press). 
Schmitt, Carl (2008), Constitutional Theory (Durhaam, NC: Duke University Press).

Schumpeter, Joseph A. (2010), Capitalism, Socialism and Democracy (London: Routledge).

Shapiro, Ian (2009), The State of Democratic Theory (Princeton, NJ: Princeton University Press).

Slingerland, Edward (2007), Effortless Action: Wu-Wei as Conceptual Metaphor and Spiritual Ideal in Early China (Oxford: Oxford University Press).

Tan, Sor-hoon (2003), Confucian Democracy: A Deweyan Reconstruction (Albany, NY: SUNY Press).

Tiwald, Justin (2008), “A Right of Rebellion in the Mengzi?”, Dao 7.3: 269-282. $<$ https://doi.org/10.1007/s11712-008-9071-z>

Tseng, Roy (2020), "Political Meritocracy versus Ethical Democracy: The Confucian

Political Ideal Revisited", Philosophy \& Social Criticism 46.9: 1033-1052. <https://doi. org/10.1177/0191453720948398>

Tu, Weiming 杜維明 (2002), 《杜維明文集》[The Collected Works of Tu Weiming] (武漢 Wuhan: 武漢出版社 $W u$-Han-Chu-Ban-She).

Weber, Max (1978), Economy and Society: An Outline of Interpretive Sociology (Berkeley, CA: University of California Press).

Weber, Max (1994), Political Writings (Cambridge: Cambridge University Press).

Wolin, Sheldon S. (1994), "Fugitive Democracy", Constellations 1.1: 11-25. <https:// doi.org/10.1111/j.1467-8675.1994.tb00002.x>

Xu, Fuguan 徐復觀 (1985), 《政治與學術之間》[Between Academia and Politics] (台北 Taipei: 學生書局Xue-Sheng-Shu-Ju).

Xu, Fuguan (2013), 《中國思想史論集續篇》[Further Works on the History of Chinese Thought] (北京 Beijing: 九州出版社 Jiu-Zhou-Chu-Ban-She).

Xu, Fuguan (2016), 《儒家思想與現代社會》[Confucian Thought and Modern Society] (北京 Beijing: 九州出版社 Jiu-Zhou-Chu-Ban-She).

Zaller, John (1992), The Nature and Origins of Mass Opinion (Cambridge: Cambridge University Press). 